\title{
食品成分による心不全治療の可能性
}

\author{
森本達也, ${ }^{*, a, b, c}$ 船本雅文, ${ }^{a, b}$ 砂川陽一, ${ }^{a, b, c}$ 刀坂泰史, ${ }^{a, b, c}$ 宮㠃雄輔, ${ }^{a, b, c}$ 長谷川浩二 $b$
}

\section{Noble Heart Failure Therapy Using Food Compositions}

\author{
Tatsuya Morimoto, ${ }^{*, a, b, c}$ Masafumi Funamoto, ${ }^{a, b}$ Yoichi Sunagawa, ${ }^{a, b, c}$ \\ Yasufumi Katanasaka,,$^{a, b, c}$ Yusuke Miyazaki, ${ }^{a, b, c}$ and Koji Hasegawa ${ }^{b}$ \\ aDivision of Molecular Medicine, School of Pharmaceutical Sciences, University of Shizuoka; 52-1 Yada, Suruga-ku, \\ Shizuoka 422-8526, Japan: ${ }^{b}$ Division of Translational Research, Kyoto Medical Center, National Hospital \\ Organization; 1-1 Mukaihata-cho, Fukakusa, Fushimi-ku, Kyoto 612-8555, Japan: and \\ cShizuoka General Hospital; 4-27-1 Kita Ando, Aoi-ku, Shizuoka 420-8527, Japan.
}

(Received March 30, 2018)

\begin{abstract}
Hemodynamic stresses, including hypertension and myocardial infarction, activate neurohumoral factors such as the sympathetic nervous system and the renin-angiotensin system, and can lead to the progression of heart failure. Established pharmacological agents such as angiotensin II receptor blockers (ARBs), angiotensin-converting enzyme (ACE) inhibitors, and $\beta$-blockers target extra-cellular molecules and receptors on the cell membrane. These agents have shown some efficacy for the treatment of heart failure, but the long-term survival rate of patients with heart failure remains low. Additional effective pharmacological approaches are urgently required. Our previous studies have demonstrated that curcumin, a natural polyphenol derived from the root of Curcuma longa, prevented the development of heart failure in rat models of myocardial infarction and hypertensive heart disease. However, until recently curcumin's poor water solubility and extremely low bioavailability have presented serious challenges to its clinical applicability. In recent years, highly absorbable curcumin preparations have been developed using methods such as nanoparticle formation and micellization, and there are now high expectations for their wide clinical application. Our group has developed a highly absorbable curcumin formulation called Theracurmin using nanoparticulation and surface processing techniques. Our preliminary data indicated that Theracurmin may improve left ventricular diastolic function. Furthermore, we have already completed and are currently carrying out several clinical trials using Theracurmin against heart failurerelated diseases. This paper summarizes and discusses the potential clinical applications of curcumin, focusing on our highly absorbable curcumin formulation, Theracurmin.
\end{abstract}

Key words_ curcumin; Theracurmin; heart failure; chronic obstructive pulmonary disease; diabetes mellitus; liver dysfunction

\section{1.はじめに}

わが国の江戸時代の平均寿命は 30 歳代であった

が, 1900 年 44 歳, 1950 年 61 歳, そして 2016 年に

は 男性 80.98 歳, 女性 87.14 歳と世界でも有数の 長寿国となっている。しかしながら，誰しも，病気 を患ったり，寝たきりで長生きはしたくなく，健康 で長生きしたいと願つている。病気となれば病院を

$a$ 静岡県立大学薬学部分子病態学分野（テ422-8526 静 岡市駿河区谷田 52-1), ${ }^{b}$ 国立病院機構京都医療セン 夕一展開医療研究部（T612-8555 京都市伏見区深草向 畑町 1-1), c 静岡県立総合病院（广420-8527 静岡市葵 区北安東 4 丁目 27-1)

*e-mail: morimoto@u-shizuoka-ken.ac.jp

本総説は, 日本薬学会第 137 年会シンポジウム S41 で 発表した内容を中心に記述したものである.
受診し治療を受けるが，健康な人はさらに健康にな りたいと，健康の保持増進に役立つとされる健康食 品が注目されている. ${ }^{1)}$ 中国では古くから, 「薬膳」 という中医学理論に基づいて食材と中薬とを組合せ た料理があり，わが国でも「医食同源」という言葉 がある．また，民間療法の中には，既存の医薬品と 比較しても遜色のない優れた薬理効果のある薬草を 用いているものもある。これらより，身体によいと 言われる食材や生薬の中には，未知の有効成分が含 まれている可能性がある，われわれは，健康食品と して注目されているウコンの主成分であるクルクミ ンに着目した. クルクミンは古くからインドではカ レーに用いる香辛料・着色料として，中国では漢方 として用いられ, 米国では安全な食材として認可さ 
Table 1. Various Diseases to Which Curcumin Is Expected to Be Clinically Applied

\begin{tabular}{l|l}
\hline \hline Lifestyle-related diseases & Cancer \\
\hline Myocardial infarction & Breast cancer \\
Heart failure & Improvement in QOL \\
Cardiac hypertrophy & Skin cancer \\
Arteriosclerosis & Pancreatic cancer \\
Diabetes mellitus & Kidney cancer \\
Metabolism of aldehyde & Colorectal cancer \\
Liver impairment & Oral cancer \\
\cline { 2 - 2 } Kidney/liver diseases & Infectious diseases \\
\cline { 2 - 2 } Metabolic syndrome & Malaria \\
\hline Cranial nerve diseases & HIV \\
\cline { 2 - 2 } $\begin{array}{l}\text { Alzheimer's disease } \\
\text { Parkinson's disease }\end{array}$ & Other \\
\cline { 2 - 2 } Epilepsy & Depression \\
\hline Inflammation & Muscular fatigue \\
\hline Arthritis & Osteoporosis \\
Gastric ulcer & Psoriasis \\
Pancreatitis & \\
Inflammatory bowel disease &
\end{tabular}

れている，わが国でも，健康食品やカレーだけでな く，古くからマスタード，たくあん漬や和菓子に用 いられている．さらにクルクミンには多くの薬理作 用が報告されているが（Table 1)，大部分は動物実 験やプレリミナリーなヒトでの実験であり，エビデ ンスの確立には至っていない. ${ }^{2)}$ そこで本総説で は，クルクミンを用いた新しい心不全治療の可能性 について，私達が行っている臨床試験を含め概説す る. 3$)$

\section{2. 生活習慣病と心不全}

心臟は絶えず収縮と弛緩を繰り返すというユニー クな機能を持った，高度に分化発達した器官であ る. その主な構成成分である心筋細胞は分化後も分 裂能を維持し，胎生期には活発に分裂・増殖を続け るが，出生と同時にその再生・分裂能は激減する。 血行動態的負荷など様々な刺激に反応して，心筋細 胞は病的肥大を来すとともに心臓は機能不全（心不 全）に陥る，心不全は高血圧性心疾患，弁膜症，虚 血性心疾患など種々の心疾患の共通最終像であり, この問題を解決することは臨床的に極めて重要であ る. ${ }^{4)}$
慢性閉塞性肺疾患 (chronic obstructive pulmonary disease；COPD）は，喫煙習慣を主な原因とする 肺の生活習慣病である。COPD 患者では，心血管 疾患が死亡原因の $20-30 \%$ を占めており，特に軽 症，中等症で心血管疾患による死亡が顕著に認めら れ, 5,6) 虚血性疾患の独立した危険因子の 1 つと考え られている。したがって，COPD は心血管疾患の 病態と関連性を持ち，重症度を規定する要因とな り，予後とも関連することが示唆される．実際， COPD 治療薬である長時間作用型吸入抗コリン薬 の有用性を検討した UPLIFT 試験7) 及びそのサブ解 析8) の結果において長時間作用型吸入抗コリン薬で あるチオトロピウムを使用した患者では，呼吸器機 能が改善するだけでなく心筋梗塞などの心血管合併 症のリスクが低下していた。つまり，COPD は心 血管予後を改善するための治療標的であることが示 唆された.

また，COPD だけでなく，肥満，糖尿病，脂質 異常症，高血圧などの生活習慣病が動脈硬化を進展 させ，心筋梗塞を発症させたり，直接心不全を発 症・進展することも明らかとなってきている．これ らの基礎疾患や併存症をコントロールすることによ り心不全の発症を予防するだけでなく, 予後も改善 できる.

\section{3. 高吸収クルクミンの開発}

クルクミンを臨床応用するにあたつての大きな問 題点は，経口摂取してもほとんど吸収されず，バイ オアベイラビリティが極めて低いことである．Lao らの報告によるとクルクミンを $10,12 \mathrm{~g}$ 内服したと きの最大血中濃度がそれぞれ $50.5,57.6 \mathrm{ng} / \mathrm{mL}$ で

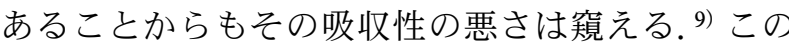
ため，生体内で効果的にクルクミンの作用を発揮さ せるためには吸収効率の改善が重要課題であり，ナ ノ粒子化，ミセル，リポソームなどの製剤化による クルクミンの吸収性向上といった研究が世界中で進 められている，中でも，BCM-95 はマイクロ粒子化 したクルクミンにターメリック油を混合した製剤で あり，ヒトにおいて天然クルクミンと比較して 6.9 倍の吸収性の向上がみられた。 ${ }^{10)}$ Meriva は大豆由 来のリン脂質であるレシチンとクルクミンがミセル を形成した製剤であり，こちらもヒト臨床試験によ り天然クルクミンよりも 29 倍吸収効率の改善がみ られている. ${ }^{11)}$ われわれはクルクミンに表面加工を 
施しナノ粒子化したセラクルミンを開発した. ${ }^{12)} こ$ のセラクルミン $30 \mathrm{mg}$ をヒトへ経口投与した試験 では，血中濃度曲線下面積 (area under the curve; AUC）は同量の天然クルクミンと比較して 27.5 倍 に達した。 セラクルミン投与時の最大血中濃度は $29.5 \mathrm{ng} / \mathrm{mL}$ であり，天然クルクミンをグラム単位 で投与した值と遜色ないものであった。このように BCM-95, Meriva，セラクルミンといったクルクミ ン製剤は天然クルクミン粉末では到達が困難な血中 濃度を低用量で容易に得られることから，今後の多 様な疾患への臨床応用が期待されている．われわれ はこの 3 剂の吸収性の比較検討を二重盲検クロス オーバー試験にて調べたところ，セラクルミンは BCM-95 に対して 16.1 倍, Meriva に対して 5.6 倍 の AUC の值が得られた. ${ }^{13)}$ また，わが国では，ク ルクミンはドリンク剂としての利用が多いことか ら，セラクルミン配合ドリンク製剂を作製し，日本 でよく販売されている他のクルクミンドリンク製剤 と血中濃度を比較した。 セラクルミン配合ドリンク 剂は, 他の市販のドリンク剤 3 種類と比較して,

AUC 0-8 h が 1.5 倍， 3.0 倍，4.0 倍と有意に高 $<$, 最高血中濃度は, 1.7 倍, 3.0 倍, 3.8 倍と有意 に高かった。 セラクルミン配合ドリンク剤は他製品 と比べて, 吸収スピードが速く, 血中濃度も高く持 続することが判明した. ${ }^{14)}$ セラクルミンは他の高吸 収性クルクミン製剤よりも高い経口吸収性が認めら れたことから，クルクミンが持つ生体内で様々な作 用を最大限に発揮させるにはセラクルミンの利用が 最も有効的であると考る．現在，国内外において， セラクルミンを用いた様々な臨床試験が進行してい る.

\section{4. クルクミンと心不全}

生体において高血圧や心筋梗塞などの負荷が加わ ると，交感神経系やレニン・アンジオテンシン系な ぞの神経体液性因子が作動し心不全の発症・進展に 関与することはよく知られている，現在までにアン ジオテンシン II 受容体拮抗薬（angiotensin II receptor blocker; ARB), アンジオテンシン変換酵 素阻害薬 (angiotensin-converting-enzyme inhibitor; ACE-I), $\beta$ 遮断薬など, 細胞膜上の受容体を標的 とした治療薬が用いられ効果を上げてきているもの の, 重篤心不全患者の 5 年生存率は依然 $50 \%$ を下 回っており，新たな治療薬の開発が望まれている.
心不全を発症するシグナル経路は複雑で多岐に渡る ため, 細胞内シグナル経路の上流よりも下流の共通 経路をターゲットとする方がより効果的な治療にな り得るのではないかと考えられ，多数の研究が行わ れてきた。そしてわれわれの研究グループでは心筋 細胞核内の転写コアクチベーターである p300 のヒ ストンアセチル化酵素（histone acetyltransferase; HAT）活性が心不全発症・進展に重要であると証

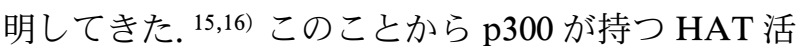
性が心不全治療のターゲットとなり得ることを見い 出した。ささに天然物クルクミンが p300の HAT

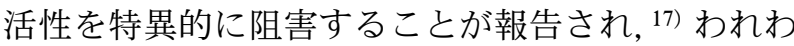
れはこのクルクミンが心不全の進展を抑制すること を高血圧性心疾患及び心筋梗塞の 2 つの慢性心不全 モデルラットを用いて証明した. ${ }^{18)}$ また，心筋梗塞 モデルラットを用いて既存心不全治療薬である $\mathrm{ACE}$ 阻害薬のエナラプリルとクルクミンの併用療 法を検討したところ，クルクミンはエネラプリルに 対し相加的に治療効果がみられた. ${ }^{19)}$ 高吸収性クル クミン製剤であるセラクルミンを用いた検討では, 天然クルクミンでは治療効果を見込めない投与量 $(0.5 \mathrm{mg} / \mathrm{kg} / \mathrm{d})$ においてでもセラクルミンはラッ 卜心筋梗塞後の心不全の悪化を予防した. ${ }^{20)}$ 以上の ことから，セラクルクミンは，クルクミンよりもよ い心不全治療薬となる可能性が示された。そこでわ れわれは，左室肥大を伴った高血圧患者を対象とし て，セラクルミンを 1 日 2 回，計 $60 \mathrm{mg}$ を 24 週間 服するプラセボ対照二重盲検比較試験を行った。セ ラクルミン内服により左室拡張能の指標である $\mathrm{E} /$ E’が有意に改善した。血圧などへの影響はなく，副 作用なども認めなかった（Fig. 1).

古くから，心不全とは左室収縮機能障害により生 じるものと考えられてきたが，最近の研究では，心 不全症例の約 30-60\% では左室駆出率が保持されて いる（preserved ejection fraction）ことが明らかと

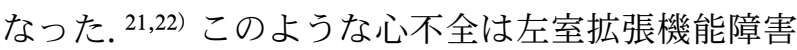
に起因するとされ，拡張不全あるいは左室収縮能の 保持された心不全（heart failure with preserved ejection fraction; HFpEF) とも呼ばれる. 拡張不全は, 高齢者，女性に多く，原因疾患として最も多いもの は高血圧である. ${ }^{21)}$ 拡張不全は駆出率の低下した心 不全 (heart failure with reduced ejection fraction;

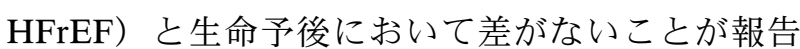




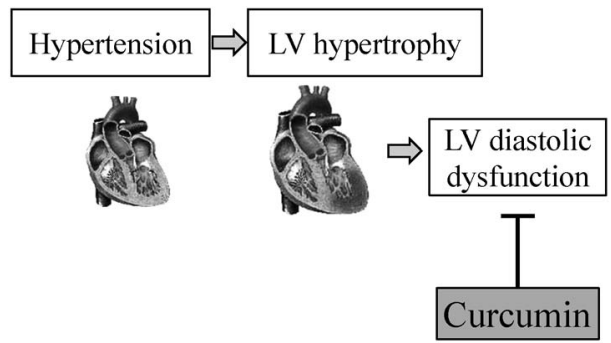

Fig. 1. Highly Absorptive Curcumin Improves Diastolic Function in Hypertensive Patients with Left Ventricular Hypertrophy

されているが, ${ }^{22)}$ 治療に関しては, HFrEF と異な り予後改善効果を示す明確な薬剂はない。例えば,

HFrEF に効果のあるレニンーアンジオテンシンーア ルドステロン系の阻害薬に関しても，PEP-CHF 試 験, ${ }^{23)}$ CHARM-Preserved 試験, ${ }^{24)}$ I-PRESERVE 試 験, ${ }^{25)}$ TOPCAT 試験 ${ }^{26)}$ などで有用性は示されな かつた。 $\beta$ 遮断薬についても, J-DHF 試験 ${ }^{27)}$ な゙ でも，心不全入院と心血管死の明確な抑制効果は示 されていない. 日本，アメリカ，欧州の最新の心不 全治療のガイドラインにも拡張不全に対する治療薬 は明らかになっていない. ${ }^{28,29)}$ クルクミンが拡張障 害を改善したことから，心不全患者の約半数を占め る拡張障害患者の治療薬となる可能性を秘めてお り，期待が大きい.

\section{5. クルクミンと COPD}

主にたばこ喫煙によって引き起こされる COPD は, 患者数が増え, 社会的に問題になっている. COPD は，冠動脈疾患の頻度が高く，肺胞隔壁の 損傷を伴う炎症性疾患であり, 肺末梢で CRP, IL-6, IL-1 $\beta$ やNFF $\alpha$ などの炎症性メディエーター が増加する.このため肺局所での炎症が体循環に波 及して全身性炎症を引き起こし，心血管疾患などの 併存症を引き起こす可能性が示唆され，COPDの 全身性疾患としての側面が注目されるようになつ た. ${ }^{30,31)}$ クルクミンには， NF- $\kappa \mathrm{B}$ を抑制することに よる抗炎症作用を持つだけでなく，活性酸素などを 除去することなどにより抗酸化作用を示すと報告さ れている. ${ }^{32)}$ 以上のことから, クルクミンは心血管 疾患と深く関与している炎症や酸化ストレスに対し て抑制効果があるのではないかと考えた。

そこでわれわれは，軽度 COPD 患者を対象にセ ラクルミンとプラセボを用いた二重盲検無作為化群 間並行比較試験を施行し，酸化ストレス・炎症マー

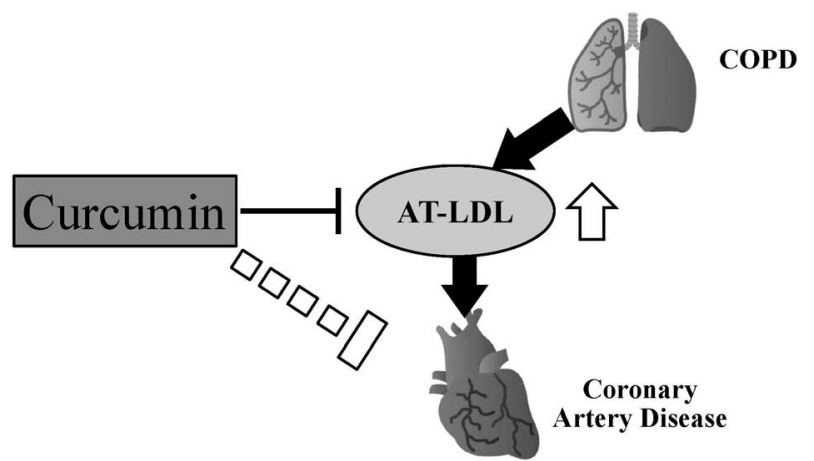

Fig. 2. Highly Absorptive Curcumin Significantly Decreased the Blood Levels of AT-LDL in Patients with Mild COPD

カーに対する効果を比較検討した。 セラクルミン群 は，プラセボ群と比較して，アテローム性動脈硬化 症を促進する酸化修飾 LDL である $\alpha 1$ アンチトリ プシンーLDL 複合体低密度リポタンパク複合体 （ $\alpha 1$-antitrypsin-LDL; AT-LDL）の変化率を有意に 低下した。すなわち，セラクルミンが AT-LDL の レベルを低下させることから，軽度の COPD 患者 における将来的な心血管イベントの予防につながる 可能性が示唆された (Fig. 2).33)

\section{6. クルクミンと肝臓}

クルクミンは一般的に肝機能を増進するといわ れ，二日酔いの予防や対策として健康食品として広 く用いられている。 アルコール性肝炎, 非アルコー ル性肝炎, 薬剂性肝障害などに効果があるとの動物 での検証が多く報告されている。しかしながら，七 トにおいては信頼できるデータは十分でない，そこ でわれわれは，セラクルミンを用いてヒトでの効果 を検証した。

アルコールを損取すると肝臓において，アルコー ル脱水素酵素（alcohol dehydrogenase; ADH）など の働きで，アセトアルデヒドに分解される．アセト アルデヒドは，アセトアルデヒド脱水素酵素（aldehyde dehydrogenase; ALDH）により無害な酢酸 へと分解され，さらには水と二酸化炭素に分解さ れ，体外へと排出される，アセトアルデヒドは有害 物質であり，その毒性によって引き起こされる症状 が二日酔いである，すなわち，二日酔いの原因はア ルコールそのものではなく，その中間代謝物である アセトアルデヒドによって引き起こされる。 そこで われわれは，アセトアルデヒドの代謝によるセラク ルミンの効果を検証するために，健常成人男性に対 
して, 飲酒 30 分前にセラクルミンをクルクミン換 算で $30 \mathrm{mg}$ 摂取するクロスオーバーヒト臨床試験 を行った. その結果, セラクルミンを摂取した群で は，摂取しなかった群と比較して，飲酒による血中 アセトアルデヒド濃度の上昇が有意に抑制され た. ${ }^{12)}$

アルコールに敏感な血液マーカーの 1 つに $\gamma$ GTP がある， $\gamma$-GTP は，肝蔵の解毒作用に関連し ている酵素の 1 つで, 肝蔵や胆管の細胞が崩壊する と血液中に流れ込んでくるため, 肝逸脱酵素と言わ れる，すなわち， $\gamma$-GTP は肝臓や胆管の細胞が壊 れた指標として利用される。 $\gamma$-GTP が高値になる 疾患には，肝炎や脂肪肝があるが，特にアルコール の飲みすぎによるアルコール性脂肪肝では，一番の 指標として重要である。そこで， $\gamma$-GTP などの肝 機能マーカーがやや高值である人を含む成人に，生 活習慣を大きく変えずに，1 カ月間セラクルミンを 朝夕 $90 \mathrm{mg}$ ずつ摂取してもらい, 肝機能マーカー 值の変化を調べた。 セラクルミンの摂取で AST (GOT) が 12\%（ $p=0.016)$, ALT (GPT) が 16\% $(p=0.041) ， \gamma$-GTP が $15 \%(p=0.010)$ と有意に 減少した。さらに被験者を層別すると，これらの マーカー值がもともと基準值を超えていた群におい てセラクルミンによる肝機能改善作用が, より顕著 となつた. ${ }^{34)} こ れ ら の$ 知見を基に, セラクルミン は, 肝機能の数值改善に役立つ機能性食品として認 可された.

クルクミンは, 以前より, 肝臓によいといわれて きたが，その作用の実証は行われてこなかった，天 然のクルクミンより優れた吸収性を有するセラクル ミンにより，飲酒時の血中アセトアルデヒド濃度上 昇の抑制や，肝機能マーカーの改善化効果がみられ たことは, クルクミンの肝蔵に対する作用を解明す る一助となると考えられる.

\section{7. クルクミンと 2 型糖尿病}

2 型糖尿病とは, 加齢, 肥満, 運動不足など生活 習慣が原因で起こる疾患であり，日本での糖尿病と 糖尿病予備群の合計は 2000 万人にのぼると言われ ている. ${ }^{35)}$ 自覚症状がそしい場合が多いが, 心血管 系イベントリスクが増大するため, 早期の適切な処 置と治療が重要である.クルクミンには膵 $\beta$ 細胞 機能や，耐糖能，インスリン抵抗性を改善する作用 を有することが示されており, ${ }^{36-38)} 2$ 型糖尿病発
症・進展を予防する効能があると考えられる. Chuengsamarn らが行ったクルクミノイド $250 \mathrm{mg}$ あるいはプラセボを糖尿病予備軍に 9 カ月間投与し た臨床試験では，プラセボ群では $16.4 \%$ が糖尿病 を発症したのに対し, クルクミン群では糖尿病発症 者はおらず， $\beta$ 細胞機能やインスリン抵抗性を改善 させた. ${ }^{39)}$ 糖尿病患者に対する血管内皮機能を検証 した試験では，8 週間のクルクミン投与によりアト ロバスタチンに匹敵する血管内皮改善作用, 酸化ス トレスや炎症系サイトカインの減少をみせた. ${ }^{40)}$ 以 上より，クルクミンには糖尿病発症の予防だけでな く，糖尿病に起因するイベントリスクを低減できる 可能性が示されており，今後更なる研究の進展が望 まれる。われわれもセラクルミンを用いて耐糖能障 害を有する患者を対象とした臨床試験を現在実施し ている（UMIN000007361）。

\section{8. まとめ}

天然クルクミン粉末よりも吸収効率のよい高吸収 クルクミン製剤セラクルミンの作製に成功し，低用 量で心不全改善効果や COPD 患者の炎症改善を認 めた。本稿で取り上げた疾患以外にも, クルクミン を用いたがん, アルツハイマー病, 統合失調症, 脂 肪肝, クローン病や潰瘍性大腸炎といった疾患を対 象としたヒ卜臨床試験が国内外で進行中であるが, クルクミンに起因する重篤な副作用についての報告

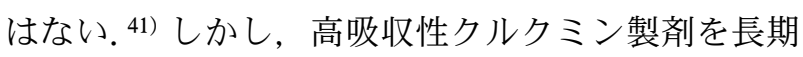
服用した場合の安全性について，医薬品との併用に よる相互作用や安全性に関しては, 今後更なる検証 が必要である. 本論文で概説したようにクルクミン には多面的作用があることから，一剂で多くの疾患 を治療ないし予防できる薬物となり得る可能性を秘 めている（Table 1)。安価で安全性が確認された機 能性食品であるクルクミンを用いた新規治療法開発 は, 今後益々増加する超高齢者の QOL の向上, さ らには医療費の削減につながることが期待され，社 会への貢献度は多大である.

利益相反本研究は株式会社セラバリューズよ り共同研究費を受けて行われた。 


\section{REFERENCES}

1) Hieda K., Sunagawa Y., Katanasaka Y., Hasegawa K., Morimoto T., Nihon Yakurigaku Zasshi, 146, 33-39 (2015) .

2) Shimatsu A., Kakeya H., Imaizumi A., Morimoto T., Kanai M., Maeda S., AntiAging Med., 9, 43-51 (2012).

3) Sunagawa Y., Katanasaka Y., Wada H., Hasegawa K., Morimoto T., PharmaNutrition, 3, 131-135 (2015).

4) Sunagawa Y., Katanasaka Y., Wada H., Hasegawa K., Morimoto T., Yakugaku Zasshi, 136, 151-156 (2016).

5) Sin D. D., Anthonisen N. R., Soriano J. B., Agusti A. G., Eur. Respir. J., 28, 1245-1257 (2006) .

6) Mannino D. M., Doherty D. E., Sonia Buist A., Respir. Med., 100, 115-122 (2006).

7) Tashkin D. P., Celli B., Senn S., Burkhart D., Kesten S., Menjoge S., Decramer M., N. Engl. J. Med., 359, 1543-1554 (2008).

8) Celli B., Decramer M., Leimer I., Vogel U., Kesten S., Tashkin D. P., Chest, 137, 20-30 (2010).

9) Lao C. D., Ruffin M. T. 4th, Normolle D., Heath D. D., Murray S. I., Bailey J. M., Boggs M. E., Crowell J., Rock C. L., Brenner D. E., BMC Complement. Altern. Med., 6, 10 (2006).

10) Antony B., Merina B., Iyer V. S., Judy N., Lennertz K., Joyal S., Indian J. Pharm. Sci., 70, 445-449 (2008).

11) Cuomo J., Appendino G., Dern A. S., Schneider E., McKinnon T. P., Brown M. J., Toqni S., Dixon B. M., J. Nat. Prod., 74, 664-669 (2011).

12) Sasaki H., Sunagawa Y., Takahashi K., Imaizumi A., Fukuda H., Hashimoto T., Wada H., Katanasaka Y., Kakeya H., Fujita M., Hasegawa K., Morimoto T., Biol. Pharm. Bull., 34, 660-665 (2011).

13) Sunagawa Y., Hirano S., Katanasaka Y., Miyazaki Y., Funamoto M., Okamura N., Hojo Y., Suzuki H., Doi O., Yokoji T., Morimoto E., Takahashi T., Ozawa H., Imaizumi A., Ueno M., Kakeya H., Shimatsu A., Wada H., Hasegawa K., Morimoto T., J.
Nutr. Sci. Vitaminol., 61, 37-44 (2015) .

14) Morimoto T., Sunagawa Y., Katanasaka Y., Hirano S., Namiki M., Watanabe Y., Suzuki H., Doi O., Suzuki K., Yamauchi M., Yokoji T., Miyoshi-Morimoto E., Otsuka Y., Hamada T., Imaizumi A., Nonaka Y., Fuwa T., Teramoto T., Kakeya H., Wada H., Hasegawa K., Biol. Pharm. Bull., 36, 1708-1714 (2013)

15) Yanazume T., Hasegawa K., Morimoto T., Kawamura T., Wada H., Matsumori A., Kawase Y., Hirai M., Kita T., Mol. Cell. Biol., 23, 3593-3606 (2003).

16) Miyamoto S., Kawamura T., Morimoto T., Ono K., Wada H., Kawase Y., Matumori A., Nishio R., Kita T., Hasegawa K., Circulation, 113, 679-690 (2006).

17) Balasubramanyam K., Varier R. A., Altaf M., Swaminathan V., Siddappa N. B., Ranga U., Kundu T. K., J. Biol. Chem., 279, 5116351171 (2004).

18) Morimoto T., Sunagawa Y., Kawamura T., Takaya T., Wada H., Nagasawa A., Komeda M., Fujita M., Shimatsu A., Kira T., Hasegawa K., J. Clin. Invest., 118, 868-878 (2008).

19) Sunagawa Y., Morimoto T., Wada H., Takaya T., Katanasaka Y., Kawamura T., Yanagi S., Marui A., Sakata R., Shimatsu A., Kimura T., Kakeya H., Fujita M., Hasegawa K., Circ. J., 75, 2151-2159 (2011) .

20) Sunagawa Y., Wada H., Suzuki H., Sasaki H., Imaizumi A., Fukuda H., Hashimoto T., Katanasaka Y., Shimatsu A., Kimura T., Kakeya T., Fujita M., Hasegawa K., Morimoto T., Biol. Pharm. Bull., 35, 139-144 (2012).

21) Bhatia R. S., Tu J. V., Lee D. S., Austin P. C., Fang J., Haouzi A., Gong Y., Liu P. P., N. Engl. J. Med., 355, 260-269 (2006).

22) Owan T. E., Hodge D. O., Herqes R. M., Jacobsen S. J., Roqer V. L., Redifeld M. M., N. Engl. J. Med., 355, 251-259 (2006).

23) Cleland J. G., Tendera M., Adamus J., Freemantle N., Polonski L., Taylor J., Eur. Heart J., 27, 2338-2345 (2006) .

24) Yusuf S., Pfeffer M. A., Swedberg K., Granger C. B., Held P., McMurray J. J., Michelson E. L., Olofsson B., Ostergren J., CHARM Investigators and Committees, Lancet, 362, 777781 (2003). 
25) Massie B. M., Carson P. E., McMurray J. J., Komajda M., McKelvie R., Zile M. R., Anderson S., Donovan M., Iverson E., Staiger C., Ptaszynska A., N. Engl. J. Med., 359, 24562467 (2008).

26) Pitt B., Pfeffer M. A., Assmann S. F., Boineau R., Anand I. S., Claggett B., Clausell N., Desai A. S., Diaz R., Fleg J. L., Gordeev I., Harty B., Heitner J. F., Kenwood C. T., Lewis E. F., O’Meara E., Probstfield J. L., Shaburishvili T., Shah S. J., Solomon S. D., Sweitzer N. K., Yang S., McKinlay S. M., N. Engl. J. Med., 370, 1383-1392 (2014).

27) Yamamoto K., Origasa H., Hori M., Eur. J. Heart Fail., 15, 110-118 (2013).

28) Ponikowski P., Voors A. A., Anker S. D., Bueno H., Cleland J. G., Coats A. J., Falk V., González-Juanatey J. R., Harjola V. P., Jankowska E. A., Jessup M., Linde C., Nihoyannopoulos P., Parissis J. T., Pieske B., Riley J. P., Rosano G. M., Ruilope L. M., Ruschitzka F., Rutten F. H., Eur. Heart J., 37, 2129-2200 (2016).

29) Yancy C. W., Jessup M., Bozkurt B., Butler J., Casey D. E. Jr., Colvin M. M., Drazner M. H., Filippatos G. S., Fonarow G. C., Givertz M. M., Hollenberg S. M., Lindenfeld J., Masoudi F. A., McBride P. E., Peterson P. N., Stevenson L. W., Westlake C., Circulation, 136, e137-e161 (2017).

30) Barnes P. J., Celli B. R., Eur. Respir. J., 33, 1165-1185 (2009).

31) Gan W. Q, Man S. F., Senthilselvan A., Sin D. D., Thorax, 59, 574-580 (2004).

32) Fan Z., Yao J., Li Y., Hu X., Shao H., Tian X., Int. J. Clin. Exp. Pathol., 8, 3451-3459
(2015).

33) Funamoto M., Sunagawa Y., Katanasaka Y., Miyazaki Y., Imaizumi A., Kakeya H., Yamakage H., Satoh-Asahara N., Komiyama M., Wada H., Hasegawa K., Morimoto T., Int. J. Chron. Obstruct. Pulmon. Dis., 11, 2029-2034 (2016).

34) Otuka Y., Sasaki Y., Imaizumi A., Hashimoto T., Kotani K., Sakurabayashi I., The Journal of Japan Mibyou System Association, 16, 331-333 (2010).

35) Ministry of Health, Labour and Welfare. "Outline of Results from 2016 National Health and Nutrition Survey."': 〈https:// www.mhlw.go.jp / stf / houdou / 0000177189. html $\rangle$, cited 10 September, 2018.

36) Jang E. M., Choi M. S., Jung U. J., Kim M. J., Kim H. J., Jeon S. M., Shin S. K., Seong C. N., Lee M. K., Metabolism, 57, 1576-1583 (2008).

37) Seo K. I., Choi M. S., Jung U. J., Kim H. J., Yeo J., Jeon S. M., Lee M. K., Mol. Nutr. Food Res., 52, 995-1004 (2008).

38) Kuroda M., Mimaki Y., Nishiyama T., Mae T., Kishida H., Tsukagawa M., Takahashi K., Kawada T., Nakagawa K., Kitahara M., Biol. Pharm. Bull., 28, 937-939 (2005).

39) Chuengsamarn S., Rattanamongkolgul S., Luechapudiporn R., Phisalaphong C., Jirawatnotai S., Diabetes Care, 35, 2121-2127 (2012).

40) Usharani P., Mateen A. A., Naidu M. U., Raju Y. S., Chandra N., Drugs $R$ D, 9, 243250 (2008).

41) Gupta S. C., Patchva S., Aggarwal B. B., AAPS J., 15, 195-218 (2013). 